maybutnikh uchyteliv [Paradigmatic modeling in the professional training of future teachers]: monohrafiya. Yurydychna literatura - Legal literature. Odesa [in Ukrainian].

Fedirchyk, T.D. (2015). Rozvytok pedahohichnoho profesionalizmu molodoho vykladacha vyshchoyi shkoly (teoretyko-metodychnyy aspekt) [Development of pedagogical professionalism of a young teacher of higher school (theoretical and methodological aspect)]: monohrafiya. Chernivtsi [in Ukrainian].

УДК 364-43:005.336.5:316.77

DOI: https://doi.org/10.35387/od.1(19).2021.92-102

\begin{tabular}{|c|c|c|}
\hline \multirow{6}{*}{$\begin{array}{l}\text { Михайлишин } \\
\text { Йосипівна } \\
\text { фрілософрських } \\
\text { проректор } \\
\text { педагогічної } \\
\text { «Прикарпатськи } \\
\text { університет } \\
\text { Василя Стефрани }\end{array}$} & $\begin{array}{l}\text { Галина } \\
\text { доктор }\end{array}$ & \multirow{6}{*}{$\begin{array}{l}\text { Mykhailyshyn Halyr } \\
\text { Philosophy, Professc } \\
\text { of Science and Edu } \\
\text { Vasyl Stefanyk } \\
\text { National University }\end{array}$} \\
\hline & наук, профресор, & \\
\hline & науково- & \\
\hline & роботи ДВНЗ & \\
\hline & ий національний & \\
\hline & ика» & \\
\hline
\end{tabular}

Мандро Леся Олегівна аспірантка кафредри теорії $i$ методики дошкільної та спеціальної освіти ДВНЗ «Прикарпатський національний університет імені Василя Стефраника»
Mandro Lesia - Postgraduate Student of the Department of Theory and Methods of Preschool and Special Education of the Vasyl Stefanyk Precarpathian National University

ORCID iD: https://orcid.org/0000-0002-5417-9419

E-mail: lesia.mandro@pnu.edu.ua

\title{
НАВИЧКИ ОСОБИСТОЇ ЕФЕКТИВНОСТІ ЯК СКЛАДОВА ПРОФЕСІЙНОЇ КОМПЕТЕНТНОСТІ СОЦІАЛЬНОГО ПРАЦІВНИКА
}

Анотація. В оглядовій статmі здійснено аналіз навичок особистої ефрективності у контексті професійної компетентності соціального працівника. Висвітлено спостереження щодо процесу активного дослідження ринку праці, який у цілому буде розширюватися $i$ одні сфрери зайнятості витісняться іншими. Зазначено, що на Всесвітньому економічному форумі інструментом успіху та економічного зростання держави визнана якісна безперервна освіта, яка забезпечить постійне вдосконалення фахівців різної сфрери зайнятості, розширення їх профресійної компетентності, вдосконалення умінь $i$ 
навиків, зокрема групи навичок особистої ефективності. У даній статті авторами визначено місце навичок особистої ефективності у структурі профресійної компетентності соціального працівника. Здійснено аналіз понять «компетентність» $i$ «компетенція». Окреслено сутність професійної компетентності соціального працівника, детально описано кожну навичку з групи навичок особистої ефрективності фрахівия соціальної сфрери. Серед них виокремлено вміння приймати рішення та працювати зі складними ситуаціями, уміння навчатися впродовж життя та управляти власним розвитком, навички планування та цілепокладання, виконання поставлених завдань, вміння грамотно розпоряджатися ресурсами та стресостійкість, конкурентоспроможність $і$ відповідальність, вмотивованість й ініціативність, гнучкість і креативність, громадську активність та адекватну самооцінку, емоційний інтелект i самоконтроль, самокритичність і самоаналіз.

Обгрунтовано, що справжній професіоналізм соціального працівника полягає не тільки у прийнятті правильних рішень в нестандартних ситуаціях, а й у здатності у процесі здійснення професійної діяльності прогнозувати результати свого впливу на клієнта. Зазначено, що навчання впродовж життя сприяє розвитку конкурентоспроможності та мобільності соціального працівника.

Ключові слова: «soft skills»; профресійна компетентність; профресійні навички; особиста ефективність; соціальний працівник.

Mykhailyshyn Halyna, Mandro Lesia

\section{PERSONAL EFFICIENCY SKILLS AS A COMPONENT OF PROFESSIONAL COMPETENCE OF A SOCIAL WORKER}

Abstract. The review article analyzes the skills of personal effectiveness in the context of professional competence of a social worker. There has been observed the process of active research on labor market, which in general will expand, and some areas of employment will be replaced by others. It is noted that the World Economic Forum recognized quality continuing education as a tool of success and economic growth of a state, which will provide continuous improvement of specialists in various fields of employment, expanding their professional competence, improving skills, including personal efficiency skills. In this article, the authors identify the place of personal effectiveness skills in the structure of professional competence of a social worker. The analysis of the concepts "competence» is carried out. The essence of the professional competence of a social worker is also determined, each skill from the group of skills of personal efficiency of a specialist in the social sphere is described in detail. These include the ability to make decisions and work with difficult situations, the ability to learn throughout life and manage their own development, planning and goal-setting skills, tasks, ability to manage 
resources and stress, competitiveness and responsibility, motivation and initiative, flexibility, activity and adequate self-esteem, emotional intelligence and self-control, self-criticism and self-analysis.

The authors also point out that the true professionalism of a social worker is not only in making the right decisions in unusual situations, but also in the ability in the process of professional activity to predict the results of their impact on the client. It is noted that lifelong learning promotes the development of competitiveness and mobility of the social worker.

Key words: soft skills; professional competence; professional skills; personal efficiency; social worker.

Постановка проблеми, їі актуальність. В умовах посилення трансформаційних процесів актуалізувалися дослідження ринку праці. Різними компаніями проводяться сотні опитувань, написана низка звітів і статей про те, які професії будуть затребувані у майбутньому та яких фрахівців потребують роботодавці. Не втратить своєї актуальності професія соціального працівника, адже з розвитком технологій появляться і нові соціальні проблеми, що потребуватимуть пошуку ефективних шляхів їх вирішення. У звіті «Майбутнє робочих місць» за жовтень 2020 р. Всесвітнього економічного форуму визначено десять важливих навичок майбутнього: аналітичне мислення та інноваційність, активне навчання i стратегія навчання, вирішення складних завдань, критичне мислення та вміння аналізувати, креативність та ініціативність, лідерство та соціальний вплив, технології, уміння програмувати, стійкість, уміння фрормувати та обґрунтовувати ідеї (The Future of Jobs Report. World Economic Forum, 2020). Інструментом успіху та економічного зростання держави визнана якісна безперервна освіта, яка забезпечить постійне вдосконалення фрахівців різної сфрери зайнятості, розширення їх профеесійної компетентності, вдосконалення умінь і навиків, зокрема групи навичок особистої ефективності. Цим обґрунтована тема дослідження статті «Навички особистої ефективності як складова професійної компетентності соціального працівника».

Аналіз останніх досліджень і публікацій. У середині $\mathrm{XX}$ ст. П. Вітмор та Дж. Фрай вивчали роль і необхідність вдосконалення м'яких навичок у військовослужбовців Сполучених Штатів Америки. Згодом поняття «soft skills» зацікавило дослідників у сфері психології, бізнесу, медицини, інформаційних технологій та освіти. Також поняття «soft skills» теоретично та практично вивчали вітчизняні та зарубіжні вчені, такі як О. Абакшина, О. Баринова, Е. Гайдученко, А. Марушев, В. Давидова, Н. Жадько, М. Чуркина, Д. Іванов, І. Канардов, І. Клюковська, А. Мирошниченко, А. Новиков, М. Чошанов, О. Чуланова, Е. Павлова, Ю. Портланд, О. Сосницька, Д. Татаурщикова, В. Шипилов. Однак «soft skills» як професійно важливі навички для майбутнього соціального працівника ще не були предметом наукового аналізу в Україні, що й зумовило вибір теми публікації.

Мета статті - визначити місце навичок особистої ефективності у 
структурі професійної компетентності соціального працівника.

Виклад основного матеріалу дослідження. Закон України «Про вищу освіту» визначає поняття «компетентність» як «здатність особи успішно соціалізуватися, навчатися, провадити професійну діяльність, яка виникає на основі динамічної комбінації знань, умінь, навичок, способів мислення, поглядів, цінностей, інших особистих якостей» (Закон України «Про вищу освіту», 2014).

Профресійна компетентність соціального працівника - сукупність профресійних знань, умінь, навичок, а також способів виконання професійної діяльності, що ґрунтується на його спрямованості та досвіді. Професійну компетентність соціального працівника визначають наявність в нього двох груп навичок: «hard skills» - професійні, технічні навички, які можна наочно продемонструвати (навички ведення професійної документації, соціальної та вікової психології, форм і методів соціальної роботи тощо); «soft skills» - навички, прояв яких складно відстежити, перевірити і наочно продемонструвати (комунікативні та управлінські) (Михайлишин, Кудла, 2018).

У структурі «soft skills» чільне місце посідає група навичок особистої ефективності: вміння приймати рішення та працювати зі складними ситуаціями, уміння навчатися впродовж життя («lifelong learning») та управляти власним розвитком, навички планування й цілепокладання, виконання поставлених завдань, вміння грамотно розпоряджатися ресурсами (часом, грошима, здоров'ям) та стресостійкість, конкурентоспроможність та відповідальність, вмотивованість та ініціативність, гнучкість та креативність, громадську активність та адекватну самооцінку, емоційний інтелект та самоконтроль, самокритичність та самоаналіз. Рівень їх сформованості основним чином впливає на результативність життя та професійної діяльності.

Вміння приймати рішення та працювати у складних ситуаціях проявляється у ґрунтовному аналізі конкретної ситуації та здатності соціального працівника добирати і використовувати найбільш оптимальні способи та прийоми діяльності в умовах змін. Соціальний працівник має виявляти творчий підхід у рішеннях, що приймаються, знаходити нові способи дій тощо. При цьому успішність дій залежить від спостережливості, професійного мислення, його логічності, уяви, що, у свою чергу, формує професійну винахідливість.

Звідси також випливає важливість розвитку відповідальності. Справжній професіоналізм соціального працівника полягає також у здатності у процесі здійснення професійної діяльності прогнозувати результати свого впливу на клієнта, враховуючи його вікові, індивідуальні особливості, умови життя тощо. Це пов'язано з умінням концентрувати і розподіляти свою увагу в незвичних умовах, що дозволяє швидко орієнтуватись у складних ситуаціях, забезпечує гнучкість мислення, швидкість і точність реакції, рухливість нервових процесів, що уможливлює швидку адаптацію у незнайомих умовах.

Необхідність вміти навчатися впродовж життя (lifelong learning) та 
управляти власним розвитком добре видно на прикладі досвіду професійної діяльності соціального працівника у США, де діє складна система ліцензування професійної діяльності. Фахівець із соціальної роботи у Сполучених Штатах Америки проходить довгий шлях професійного становлення. Щоб стати Ліцензованим клінічним соціальним працівником необхідно: отримати диплом бакалавра та диплом магістра соціальної роботи з ЗВО акредитованого Радою з Освіти по соціальній роботі; оформити реєстрацію в Раді з Поведінкових Наук у якості соціального працівника - інтерна; задокументувати опрацювання більше 3000 годин 3 клінічної практики під супервізією акредитованого ліцензованого соціального працівника (3-5 років); години практики включають: оцінку, діагностику, планування, психотерапію. Також необхідно пройти додаткові курси і постійно навчатися; скласти іспит 3 права, етики конкретного штату та інші специфічні спеціалізовані курси та спеціалізований тренінг; екзамен 3 клінічної практики. Отримавши кваліфікацію, фахівець повинен постійно вдосконалюватися, адже ліцензію потрібно оновлювати щорічно, проходячи необхідне навчання. Особливо важлива бездоганна репутація. Така регуляція потрібна для захисту прав споживача та гарантії якісного надання допомоги (Ростальна, 2020).

Навчання впродовж життя сприяє розвитку конкурентоспроможності та мобільності соціального працівника. Такі навички дозволяють фахівцю швидко й безболісно адаптуватися до суспільних змін, наукового та технічного прогресу й нових видів професійної діяльності, форм спілкування за умови збереження позитивного внутрішнього психологічного та енергетичного потенціалу й гармонії. Йому потрібно бути соціально активним, здатним до саморозвитку й модернізації власної діяльності; швидко й успішно освоювати нові технології, вдосконалювати власні знання та вміння; швидко змінювати вид праці переключаючись на іншу діяльність. Ця система передбачає високий ступінь розвитку узагальнених професійних знань, а також готовність відбирати й реалізовувати оптимальні способи виконання завдань; забезпечує рухливість працівника, його здатність до саморегулювання, самоорганізації, швидкої зміни стану, статусу, соціальної категорії, уміння швидко орієнтуватися в ситуації. Професійна мобільність не обмежується рамками однієї галузі і розглядається як можливість професійної та особистісної самореалізації у будь-якій сфері соціально-економічної та соціокультурної діяльності.

Аналізуючи навички цілепокладання, доцільно згадати про методику постановки цілі SMART (Specific Measurable Achievable Relevant Time-bounded). «Specific» означає конкретність цілі (вона повинна бути максимально чітка, коректна, відповідати тому, що справді потрібно досягти); «measurable» говорить про вимірність цілі (визначені критерії оцінки та формат вимірювання, оскільки мета піддається виміру, можна оцінити весь шлях до її досягнення і конкретний етап перебування на шляху до неї); «achievable» акцентує на досяжності поставленої мети (важливо проаналізувати наявність необхідних для досягнення цілі 
pecyрсів); «relevant» означає реалістичність, a «time-bounded» чітку визначеність цілі в часі (тобто є конкретна дата досягнення мети, розуміння іï користі чи шкоди). У процесі цілепокладання необхідно визначити сильні сторони, обов'язки, що потрібно делегувати, продумати по кілька варіантів отримання бажаного результату, врахувати, що ціль може мінятися в ході здійснення фахової діяльності та отриманні нової інформації. Тому потрібно щоразу відповідати на питання: «Чи мета $є$ актуальною на даний час?».

Умотивованість і виконання поставлених завдань тісно взаємопов'язані. Наявність фрактору мотивації дає можливість перетворювати знання, уміння та навички на засоби особистісного й профресійного зростання. Тим самим посилюється якість діяльності соціального працівника-професіонала. Мотивація $€$ соціокультурним феноменом й зумовлює соціальні дії індивіда. Залучення його до соціуму відбувається під впливом системи норм, правил і цінностей, рольового статусу, культурних традицій. Отже, на часі - дослідження змісту й особливостей мотиваційної системи, адже вони змінюються залежно від потреб клієнта, обставин і професіоналізму фахівця із соціальної сфери. Передусім йдеться про матеріальну, організаційну, соціальну та інформаційну мотивацію. Розкрити сутність поведінки і діяльності суб'єктів та об'єктів соціальної роботи допоможе їх детальне вивчення.

Виконання поставлених завдань передбачає використання інструментів досягнення поставленої мети, щоденні активні дії, фокусування та рух встановленою траєкторією. Важливою є декомпозиція - структурування мети на малі цілі, кроки, а також використання списку почергових дій. У процесі здійснення професійної діяльності доцільно здійснювати оцінку ефективності дій, визначати, що впливає на отримання бажаного результату. Корисним для соціального працівника буде володіння навичками нетворкінгу (англ. networking), що полягає в обміні інформацією між людьми, об'єднаними спільними професійними та/чи особистими інтересами, що зазвичай відбувається в неформальній обстановці. В основі нетворкінгу - побудова міцних довірливих довгострокових відносин за принципом соціальної мережі. Швидке та ефективне вирішення складних життєвих і робочих завдань за допомогою налагодження взаємозв'язків з друзями та знайомими - основна мета нетворкінгу.

Навички планування та вміння грамотно розпоряджатися ресурсами передбачає дотримання наступних принципів: пріоритетності, ефективності, оптимальності. Оскільки події важко запланувати у цілому, варто свій час розподілити на 3 групи: $60 \%$ - запланований час провідної діяльності; 20 \% - спонтанна активність; 20 \% - непередбачений час. Для ефрективного використання робочого часу важливо враховувати психологічно обґрунтовані режими праці та відпочинку. Науковці доводять, що працездатність людей протягом робочого дня змінюється за стадіями. Початок робочого дня називається періодом напрацювання. Його тривалість залежить від стану і підготовленості людини, а також від 
складності роботи, що виконується. Подальші 2-3 години характеризуються максимальною працездатністю, після чого вона знижується. Друга половина робочого дня відрізняється від першої більш низьким рівнем працездатності. Тому розв'язання складних питань треба планувати у періоди найбільшої працездатності. У післяобідній період краще виконувати навантаження, що потребує менших зусиль. 3-поміж основних принципів розподілу часу науковцями обґрунтовано такі: принцип встановлення пріоритетів (визначення цілей, яких необхідно досягати щодня); принцип ефективності (виконувати кожну задачу вчасно, не зволікаючи 3 їі вирішенням); принцип пріоритетного планування (визначивши найважливіші завдання, можете зосередитися на їх виконанні, а потім, за наявності часу, й на інших, менш важливих); принцип пошуку вигоди від управління часом (навчитися виділяти істотне й відрізняти його від другорядного). Ефективне управління часом не лише дозволяє зробити робочий день продуктивнішим, а й знімає психологічні перевантаження, що виникають внаслідок браку часу і негативно впливають на продуктивність праці та задоволеність нею і собою (Войлісовська, 2016).

3-поміж навичок особистої ефективності соціального працівника також виокремлюємо емоційний інтелект, стресостійкість. Емоційний інтелект (EI) (англ. emotional intelligence) розуміємо як групу ментальних навичок, що лежать в основі усвідомлення, розуміння власних емоцій та емоцій оточуючих, їх управління. Модель емоційного інтелекту містить чотири компоненти: самосвідомість (емоційна самосвідомість, самооцінка, впевненість в собі); соціальна свідомість (емпатія, корпоративна свідомість, орієнтація на надання послуги); володіння собою (емоційний самоконтроль, дії довіри, поведінкова свідомість); менеджмент взаємин (розвиток інших людей, вплив на оточуючих). Високий рівень емоційного інтелекту дозволить фахівцю із соціальної роботи розуміти власні емоції та почуття інших людей, вміло керувати своєю емоційною сферою, легко досягати своїх цілей під час взаємодії з оточенням. Емоційний інтелект відіграє основну роль у формуванні навичок стресостійкості, що визначається як здатність демонструвати адекватну поведінку у стресових ситуаціях у межах професійної діяльності. Важливого значення набуває й розвиток вміння регулювати власний емоційний стан задля збереження психічної рівноваги та ефективної професійної діяльності, а також життєздатності та здоров'я; здатність до прийняття правильних рішень у кризових і критичних ситуаціях; здатність тривалий час зберігати терпимість, толерантність і наполегливість у досягненні успіху у розв'язанні професійних задач.

Навичка креативності передбачає здатність соціального працівника відмовитися від стереотипних способів мислення та схильність до руйнування усталеного, звичайного порядку походження ідей у процесі мислення. За Дж. Гілфордом, креативній людині притаманні такі риси: швидкість думки (кількість ідей, що виникають за одиницю часу); гнучкість думки (здатність перемикатися з однієї ідеї на іншу); оригінальність (здатність виробляти ідеї, що відрізняються від загальноприйнятих 
поглядів); допитливість (чутливість до проблем у навколишньому світі); здатність до розробки гіпотези; ірреальність - логічна незалежність реакції від стимулу; франтастичність (повна відірваність відповіді від реальності за наявності логічного зв'язку між стимулом і реакцією); здатність розв'язувати проблеми, здатність до аналізу та синтезу; здатність удосконалити об'єкт, додаючи деталі. Роботодавці потребують працівників, які здатні бачити незвичне у буденних речах, творчо підходять до вирішення завдань та успішно з ними справляються. Адже у сучасному мінливому світі реалізація творчого задуму, досягнення успіху, пошук нових шляхів для саморозвитку та самореалізації можливі за умови наявності здатності людини генерувати нестандартні ідеї, відмови від традиційних схем мислення.

Гнучкість (динамічність) фрахівця із соціальної роботи проявляється в постійній зміні змісту та форми роботи (гнучкість мислення, соціальна і емоційна гнучкість). Гнучкість мислення соціального працівника дозволяє швидко й легко переключатися з однієї ідеї на іншу, переходити від явищ одного класу до явищ іншого, встановлювати між об'єктами, процесами асоціативні зв'язки. У соціальній діяльності гнучкість мислення не тільки дає змогу швидко реагувати на ситуацію і відповідно на зміни умов ситуації, змінювати способи дій, трансформувати свій досвід, а й зумовлює здатність до імпровізації як миттєве знаходження незвичних, нових i найбільш оптимальних способів діяльності. Адже отримання очікуваних результатів діяльності соціальних працівників базується на втручанні та впливі людини, яка спрямовує хід соціальних процесів за власним баченням. Емоційна гнучкість забезпечує здатність успішно здійснювати необхідну діяльність у складних емоційних умовах з оптимальним виявом емпатійності. У соціальній діяльності вона виявляється як співвідношення емоційної стійкості та емоційної експресивності (чуйності), що дає змогу сприймати та усвідомлювати емоційні переживання. Для діяльності соціальних працівників виявляється у спілкуванні з іншими в ході розв'язання економічних проблем, у реалізації чуйності, емоційної стабільності.

Соціальна гнучкість передбачає здатність змінювати напрями, впливи, дії для досягнення гармонії, порозуміння, взаємопристосованості та задоволення. Це відбувається завдяки м'якому коригуванню цілей, способів, умінь, станів, згідно з ситуаціями, що змінюються. Вона $\epsilon$ безпосередньою умовою успішного професійного спілкування. Соціальна гнучкість в діяльності фахівців соціальної сфери проявляється у великій кількості поведінкових стратегій, при застосуванні яких необхідно дотримуватися морально-етичних засад.

Навички громадської активності та ініціативності фрормуються та розвиваються на основі системи власних ціннісних орієнтацій 3 урахуванням надбань суспільства, норм права, вимог держави та спрямовує діяльність людини на зміцнення громадянських відносин та взаємодії 3 владою. Громадська активність соціального працівника базується на громадській позиції (ступені зрілості людини як громадянина 
та усвідомлення свого місця у процесі державотворення). Це один із можливих способів впливу на прийняття соціально-політичних рішень, просування проєктів, покликаних вирішити актуальні соціальні проблеми. Ініціативність та громадська активність фрахівця із соціальної роботи уможливлює здійснення впливу на рішення, які приймаються в суспільстві; участь у розробці законів або розпоряджень; внесення змін або відхилення правових актів; просування групових та суспільних інтересів.

Здійснення ефективної професійної діяльності соціального працівника також залежить від рівня сформованості адекватної самооцінки на основі навичок самоаналізу, самокритичності та самоконтролю. Самооцінка являє собою емоційно насичене усвідомлення самого себе як особистості, враховуючи власні здібності, етичні якості і вчинки. Вона сприяє визначенню взаємин фахівця із соціальної роботи з оточенням, його самокритичність та вимогливість, сприйняття успіхів і невдач. Тому самооцінка впливає на професійне становлення та розвиток людини. Адекватна самооцінка особи сприяє можливості правильно співвідносити власні сили із завданнями різної складності та вимоги оточення.

Висновки і перспективи подальших досліджень. Професійна підготовка соціальних працівників потребує особливої уваги, адже вони працюють як посередники між державою і незахищеними категоріями населення та надають соціальні послуги. Попередження та вирішення низки сучасних суспільних проблем вимагає від них ґрунтовних знань, професійно та життєво важливих умінь і навичок, зокрема, вмінь приймати рішення та працювати зі складними ситуаціями, навчатися впродовж життя та управляти власним розвитком, сформованих навичок планування та цілепокладання, виконання поставлених завдань, вмінь грамотно розпоряджатися ресурсами. Винятково важливого значення також набувають стресостійкість, конкурентоспроможність, відповідальність, вмотивованість, ініціативність, гнучкість та креативність, громадську активність та адекватну самооцінку, емоційний інтелект та самоконтроль, самокритичність і самоаналіз. Пошук оптимальних шляхів фрормування та вдосконалення навичок особистої ефективності соціального працівника залишається актуальним завданням для сучасних закладів вищої освіти. Адже на них покладено створення умов для підготовки висококваліфікованого фахівця, який володіє універсальними вміннями й навичками й здатен до життєдіяльності у швидкоплинних умовах на тлі посилення вимог ринку праці. Це можливо тільки при створенні системи тренування м'яких навичок («soft skills»).

У подальшому зосереджуватимемо нашу увагу на науковому обґрунтуванні педагогічних умов розвитку у майбутніх соціальних працівників перелічених вище навичок.

\section{Список використаних джерел}

Войлісовська, В. (2016). Оптимізація робочого часу. Особистий та командний тайм-менеджмент, квітень. URL: https://i.factor.ua/ukr/journals/ds/2016/april/issue-4/article-17119.html 
Закон України «Про вищу освіту» від 01.07.2014 р. № 1556-VII. Ред від 23.04.2021. URL: https://zakon.rada.gov.ua/laws/show/1556-18\#Text

Михайлишин Г. \& Кудла, Л. (2019). Ретроспективний аналіз розвитку поняття «soft skills» (м'які навички). Еврика - XX: збірник студентських наукових праць. Івано-Франківськ: Прикарпат. нац. ун-т ім. В. Стефаника, $102-104$.

Ростальна, М. (2019). Соціальна робота у США: ліцензування соціальних працівників. URL: P4EC_Webinar_5_20191223_ukr.pdf.

Arat, M. (2014). Acquiring soft skills at university. Journal of Educational and Instructional Studies in the World, 4(3), 46-51. URL: http://www.wjeis.org/FileUpload/ds217232/File/09.arat.pdf

Baklashova, T. A., Galishnikova E, M., \& Khafizova L, V. (2015). The effects of education on tolerance: research of students' social and ethnic attitudes. Mediterranean Journal of Social Sciences, 6 (1S3), 335-340. DOI: http://doi.org/10.5901/mjss.2015.v6n1s3p335

Boyer, W., \& Crippen, C.L. (2014). Learning and teaching in the 21st century: An education plan for the new millennium developed in British Columbia, Canada. Childhood Education, 90(5), 343-353. DOI: http://doi.org/10.1080/00094056.2014.952218

Cimatti, B. (2016). Definition, development, assessment of soft skills and their role for the quality of organizations and enterprises. International Journal for Quality Research, 10(1), 97-130. DOI: http://doi.org/10.18421/ijgr10.01-05

The Future of Jobs Report. World Economic Forum, october 2020. URL: http://www3.weforum.org/docs/WEF_Future_of_Jobs_2020.pdf.

\section{References (translated and transliterated)}

Voylisovs'ka, V. (2016). Optymizatsiya robochoho chasu [Optimization of working time]. Osobystyy ta komandnyy taym-menedzhment - Personal and team time management, kviten'. URL: https://i.factor.ua/ukr/journals/ds/2016/april/issue-4/article-17119.html [in Ukrainian].

Zakon Ukrayiny «Pro vyshchu osvitu» [Law of Ukraine "On Higher Education»]: vid 01.07.2014. № 1556-VII. URL: https://zakon.rada.gov.ua/laws/show/155618\#Text [in Ukrainian].

Mykhaylyshyn, H., Kudla, L. (2019). Retrospektyvnyy analiz rozvytku ponyattya «soft skills» (m"yaki navychky) [Retrospective analysis of the development of the concept of «soft skills»]. Evryka - XX : zbirnyk student·s'kykh naukovykh prats'. Ivano-Frankivs'k: Prykarpat. nats. un-t im. V. Stefanyka, 102-104 [in Ukrainian].

Rostal'na, M. (2019). Sotsial'na robota u SSHA: litsenzuvannya sotsial'nykh pratsivnykiv [Social work in the USA: licensing of social workers]. URL: P4EC Webinar 5_20191223_ukr.pdf [in Ukrainian].

Arat, M. (2014). Acquiring soft skills at university. Journal of Educational and Instructional Studies in the World, 4(3), 46-51. URL: http://www.wjeis.org/FileUpload/ds217232/File/09.arat.pdf [in English].

Baklashova, T.A., Galishnikova E, M., \& Khafizova L, V. (2015). The effects of education on tolerance: research of students' social and ethnic attitudes. Mediterranean Journal of Social Sciences, 6 (1S3), 335-340. DOI: http://doi.org/10.5901/mjss.2015.v6n1s3p335 [in English]. 
Boyer, W., \& Crippen, C.L. (2014). Learning and teaching in the 21st century: An education plan for the new millennium developed in British Columbia, Canada. Childhood Education, 90(5), 343-353. DOI: http://doi.org/10.1080/00094056.2014.952218 [in English].

Cimatti, B. (2016). Definition, development, assessment of soft skills and their role for the quality of organizations and enterprises. International Journal for Quality Research, 10(1), 97-130. DOI: http://doi.org/10.18421/ijqr10.01-05 [in English].

The Future of Jobs Report. World Economic Forum, october 2020. URL: http://www3.weforum.org/docs/WEF_Future_of_Jobs_2020.pdf [in English].

УДК 378.046 .4

DOI: https://doi.org/10.35387/od.1(19).2021.102-113

Misailova Kseniia - PhD student at the Ivan Ziaziun Institute of Pedagogical and Adult Education of NAES of Ukraine; Head of the Aviation English Department at the Ivan Kozhedub Kharkiv National Air Force University

\begin{abstract}
Місайлова Ксенія Валентинівна - аспірантка Iнституту педагогічної освіти і освіти дорослих імені Івана Зязюна НАПН України; завідувачка кафредри авіаційної анелійської мови Харківського національного університету Повітряних Сил імені Івана Кожедуба
\end{abstract}

ORCID iD: https://orcid.org/0000-0001-5444-6823

E-mail:kseniiamisailova555@gmail.com

\section{INTRODUCTORY TRAINING FOR AVIATION ENGLISH TEACHERS}

Abstract. The article raises the issue of creating a system of introductory training for Aviation English teachers for successful realization of teaching in military and civilian institutions of higher education in the aviation industry.

A new scientific and pedagogical concept is introduced and argued, as «introductory training for teachers». Such training is necessary for teachers of higher educational establishments when transferring to higher positions into the institutions with another specialization, like transition from a civilian to a military institution to continue teaching career while teaching a foreign language for professional purposes. It was stressed in the article that in the context of transformation processes in Ukraine's transition to NATO and ICAO standards it is necessary firstly to train qualified teaching and instructional staff for the Air Force of the Armed Forces of Ukraine to ensure high quality of future specialists training.

The article considers the requirements set by the International Civil Aviation Organization (ICAO) for teachers who teach Aviation English to pilots and air traffic controllers in higher education institutions or on the basis of accredited training organizations. The conclusion on expediency and necessity 